\title{
Scale for Identification of Characteristics of Giftedness: Internal structure analysis
}

\author{
Escala de Identificação de Características de Altas \\ Habilidades/Superdotação: análise da estrutura interna
}

\author{
Priscila ZAIA ${ }^{1}$ \\ ORCID iD 0000-0002-1025-6240 \\ Tatiana de Cássia NAKANO ${ }^{1}$ \\ ORCID iD 0000-0002-5720-8940 \\ Evandro Morais PEIXOTO \\ ORCID iD 0000-0003-1007-3433
}

\begin{abstract}
Procedures used for identifying giftedness have been widely discussed in the literature. The present study aimed to investigate the evidence of validity based on the internal structure of a self-report scale to identify characteristics of giftedness. The sample consisted of 276 Elementary and Middle School students, aged between 9 and 12 years, and was $60.0 \%$ female. The instrument used was the first version of this scale, which was composed of 44 items related to the topic. Exploratory Factor Analysis was carried out, and the results revealed a two-factor solution, explaining $40.4 \%$ of the total variance. The first factor was denominated Socio-emotional Characteristics, and the second factor was denominated Cognitive Characteristics. The results corroborate the data in the scientific literature, which suggest that giftedness is a multidimensional construct that encompasses attributes that go beyond the intellectual scope.
\end{abstract}

Keywords: Gifted; Multivariate analysis; Self report; Test validity.

\section{Resumo}

As diversas formas de identificação das Altas Habilidades/Superdotação têm sido amplamente discutidas na literatura. O presente estudo objetivou investigar as evidências de validade da estrutura interna de uma escala de autorrelato para identificação de características associadas ao tema. A amostra constituiu-se de 276 estudantes de ensino fundamental, com idades entre 9 e 12 anos, sendo 60,0\% do sexo feminino. O instrumento respondido foi a primeira versão desta

$\checkmark \nabla \nabla$

1 Pontifícia Universidade Católica de Campinas, Centro de Ciências da Vida, Programa de Pós-Graduação em Psicologia. Av. John Boyd Dunlop, s/n., Jd. Ipaussurama, 13060-904, Campinas, SP, Brasil. Correspondência para/Correspondence to: T.C. NAKANO. E-mail: <tatiananakano@hotmail.com>.

2 Universidade de Pernambuco, Curso de Graduação em Psicologia, Departamento de Psicologia. Garanhuns, PE, Brasil.

Article based on the doctoral dissertation of P. ZAIA entitled "Construção de Escala de autorrelato para identificação de características associadas à Superdotação”. Pontifícia Universidade Católica de Campinas, 2014.

Support: Conselho Nacional de Desenvolvimento Científico e Tecnológico (Process no 130216/2013-5).

$\boldsymbol{\nabla} \boldsymbol{\nabla} \boldsymbol{\nabla}$

Como citar este artigo/How to cite this article

Zaia, P., Nakano, T. C., \& Peixoto, E. M. (2018). Scale for Identification of Characteristics of Giftedness: Internal structure analysis. Estudos de Psicologia (Campinas), 35(1), 39-51. https://doi.org/10.1590/1982-02752018000100005 
escala composta por 44 afirmações relacionadas ao tema. O procedimento de Análise Fatorial Exploratória apresentou uma solução de dois fatores, os quais explicariam $40,4 \%$ da variância total. O primeiro fator foi chamado de Características Socioemocionais e o segundo, Características Cognitivas. Os resultados corroboram a literatura científica, a qual compreende o construto como multidimensional, incluindo atributos que vão além do âmbito intelectual.

Palavras-chave: Superdotados; Análise fatorial; Autorrelato; Validade do teste.

Historically, the scientific literature has shown that over the years the concept of intelligence has changed from a single-factor (factor g) and twofactor (fluid and crystallized intelligence) views to a multidimensional concept (Almeida \& Primi, 2010; Ekinci, 2014; Kaufman \& Sternberg, 2008). This fact has brought about important changes in the concept of giftedness, especially in terms of understanding that intellectual abilities alone are not enough to define this complex phenomenon (Plucker \& Callahan, 2014).

Unlike the longstanding conception of the exclusive association between giftedness and intelligence (measured by Intelligence Quotient tests only), a practice that excluded many talents, the interaction between emotional characteristics and the recognition of the influence of the cultural and social contexts on the formulation and promotion of this concept have been considered to understand individuals' behaviors (Jones, Greenberg, \& Crowley, 2016; Plucker \& Callahan, 2014). Therefore, important theoretical models explaining giftedness have been developed based on a multidimensional view of the phenomenon, together with an important review of intelligence models. These models include the Differentiating Model of Giftedness and Talent (Gagné, 2014), the Three-Ring Conception of Giftedness (Renzulli, 2012; 2014), and the Wisdom, Intelligence, and Creativity Synthesized Model (Sternberg, 2003; 2005).

Based on this expanded conception, Brazilian education policies, especially the Secretariat of Education, Resolution $n^{\circ}$ 81/2012, consider gifted individuals "those who have high abilities in one or more areas of human knowledge, such as the intellectual, academic, psychomotor ability, and leadership and creativity, including the motivation to learn and perform tasks in subjects of their interests" (Secretaria da Educação Especial, 2012,

40 can be cognitive or may include social behaviors, attributes and abilities, and can be called noncognitive characteristics; the attributes in these two categories are not mutually exclusive (Jones et al., 2016).

Based on this conception, three important aspects of giftedness have been recognized by researchers as being essential to understand the phenomenon: (1) it is a complex concept that encompasses the cognitive, emotional, social, motivational, and other spheres (2) it has many facets and their manifestation will be characterized by the individuality and exceptionally particular combination in each individual, and (3) the criterion used to evaluate the phenomenon may differ with respect to the attempt to understand all aspects involved in the construct (Panov, 2002).

In terms of the first aspect discussed above, features related to intelligence alone are no longer enough to understand gifted individuals. Thus, the so-called non-cognitive competencies have also been recognized as constituent elements of the phenomenon (Olszewski-Kubilius, Subotnik, \& Worrell, 2015). Therefore, it has been noticed that non-intellectual traits (motivation, persistence, empathy, perfectionism, ethical concerns, responsibility, curiosity, and sense of humor, among others) have been considered as important as the commonly measured cognitive traits for promotion and full development of Giftedness (Almeida, Fleith \& Oliveira, 2013; G. A. Davis, Rimm, \& Siegle, 2011; Johnsen, 2011; Lima, 2008; Ourofino \& Guimarães, 2007; Renzulli, 2012; Sabatella, 2012).

The second aspect refers to the importance of recognizing different forms of expression of Giftedness. This has been detected in most of the theoretical models that explain the phenomenon or in theories of intelligence that also support this conception. Among the previously mentioned models and theories, Gagné (2014) conceptualizes 
gift or talent as four aptitude domains: intellectual, creative, socio-affective, and sensorimotor. Similarly, Sternberg (2003) considers wisdom, intelligence, and creativity as essential elements and, finally, Renzulli (2012) recognizes the existence of two types of giftedness: academic and creativeproductive. Although it cannot be characterized as a model of giftedness, the model proposed by Gardner (1998) includes eight different types of Intelligence (linguistic, logical-mathematical, spatial, musical, naturalist, body-kinesthetic, interpersonal, and intrapersonal), which, due to their comprehensiveness, offer important contributions to the areas of giftedness.

Thus, it is observed that all models and theories consider the existence of manifestations of different types of high abilities, emphasizing the heterogeneity of the phenomenon by recognizing the individual differences in its expression. The recognition of this differentiation is important to highlight the degree of asynchrony that can vary from individual to individual, as well as the recognition that gifted behaviors are present in different areas and should be considered in all realms of performance, and not separately, including both Intellectual and emotional areas (Folsom, 2009).

Although the types of giftedness are not mutually exclusive, they can occur isolated or combined in an individual or even along with a disability (in cases called dual exceptionality, in which there is an area where a high ability is present together with a disability), the distinction is essential for determining the path of development of gifted behaviors and to meet the specific needs of gifted individuals, according to their particularities. Such diversity has attracted researchers' interest in investigating how these individuals differ from their peers and in understanding their different profiles and interests (Wellisch \& Brown, 2012). This perception refers to the third aspect, as emphasized by Panov (2002), i.e., the need to use different criteria in the evaluation of the phenomenon as an attempt to understand all aspects involved in the construct.

The scientific literature has repeatedly recommended the adoption of a comprehensive process that considers a combination of quantitative and qualitative measures, case studies and observations, parents and teachers' recommendations, and selfnomination by the child; each one with its due importance (Heller, 2013). This can take place by combining objective and subjective techniques, whose range may help in ensuring the recognition of these behaviors (Renzulli, 2012). Thus, it is hoped that this process can consider both, students with traditional high academic and cognitive performance and those who demonstrate skills developed in a variety of other areas (Renzulli, 2014). Considering this, it can be said that the identification process is challenging because it results from the evaluation of the presence of the intensity and consistency in the behaviors associated with the phenomenon. It should be a continuous process which is not based only on a report indicating whether the individual is gifted (Pérez \& Freitas, 2014).

The recognized importance of the combining techniques and instruments for the identification of the gifted individuals (Mun, 2016) has created an international scenario in which the assessment has been carried out using a variety of methods and techniques based mainly on the investigation of intellectual domain, performance scales, achievement, creativity, nominations by parents and teachers, and behavior verification (McClain \& Pfeiffer, 2012). In Brazil, however, the situation is quite different. Although, according to the Ministry of Education (Ministério da Educação, 1999) guidelines, the assessment should aim at aspects such as divergent thinking, intellectual level, self-concept, and aptitude and creativity and could be complemented by the use of questionnaires of Interests, social and emotional adjustment rating scales, and interviews and personality assessment tools, as emphasized by Mettrau and Reis (2007), there are different challenges to be faced. One of them is the lack of specific tests that have been developed and approved for identification and evaluation of giftedness.

The lack of instruments, whether objective (performance tests) or subjective (external evaluation or self-report scales) developed specifically to evaluate the particularities of gifted individuals, 
can be confirmed by searching the Psychological Testing Evaluation System of the Conselho Federal de Psicologia (CFP, Federal Council of Psychology) (http://satepsi.cfp.org.br/listaTesteFavoravel.cfm). Accordingly, it should be pointed out that although other tests that evaluate isolated constructs, such as intelligence, creativity, or motivation, which are available and authorized by the CFP, can be used to identify giftedness, the lack of studies investigating their psychometric properties for this population cannot be ignored. Therefore, the Brazilian scenario is still characterized by the use of non-specific tests to identify this phenomenon (Nakano, Campos, \& Santos, 2016). This justifies the need for efforts aimed at the development of psychological assessment of this specific topic, considering some aspects that deserve to be highlighted.

The first aspect concerns the fact that although psychological tests cannot be used as the only method to identify gifted individuals, the use of a multifactor comprehensive process encompassing a variety of information sources and multiple criteria established in different psychometric tests, observation, parents and teachers' evaluation, questionnaires, schoolwork done at school, and portfolios, among others, has been recommended (Nakano, Gozolli, Alves, Zaia, \& Campos, 2016; Nakano, Primi, Ribeiro, \& Almeida, 2016; Pfeiffer $\&$ Blei, 2008). The aims are to encompass a wide range of characteristics involved in the high abilities (Calero \& García-Martin, 2014; Hernández-Torrano, Férrandiz, Ferrando, Prieto, \& Férnandez, 2014) and provide information that can support the decision about the presence characteristics indicative of giftedness (Davis, Christodoulou, Seider, \& Gardner, 2011a; Milligan, 2010).

The second aspect is based on the fact that although this phenomenon is susceptible to the influence of many variables involving social, psychological, biological, educational, and environmental aspects, and it involves other important constructs, such as personality characteristics, interests, self-concept, and motivation (Gallagher, 2008; Heller, 2013; Kaufman \& Sternberg, 2008), the difficulty in identifying these individuals persists. This may due to the lack of adequate evaluation instruments, the difficulty in establishing criteria, and lack of specific identification measures, which leads to the false expectations and false negative or false positive diagnoses (Bracken \& Brown, 2006).

The third aspect to be highlighted is that regardless of the existence of many federal laws related to intervention actions aimed at the care of gifted children, there have been difficulties in identifying them and, mainly, in developing methods to evaluate them properly. These difficulties and challenges have hindered the access of many children to programs designed to motivate and promote the development of their abilities (Nakano et al., 2015).

The specificities of this area have motivated the development of a self-report scale to evaluate characteristics associated with giftedness. This type of measure has been seen as an instrument for screening gifted behaviors and have been used to complement assessments (Pfeiffer \& Petscher, 2008), due to its ease of administration. The best known instruments include the Scales for Rating Behavioral Characteristics of Superior Students, developed by Renzulli and his collaborators, designed for teachers (Renzulli, Siegle, Reis, \& Gavin, 2009); the Scale for Identifying Gifted Students, developed by Riser and McConnell (Ryser, 2011); and the Gifted Rating Scales, developed by Pfeiffer and Jarosewisch (2003). Similar instruments have been adapted or developed for use in Brazil (Cardoso \& Becker, 2014; Farias, 2012; Nakano et al., 2016; Nakano \& Siqueira, 2012). However, it is worth mentioning that only preliminary and isolated studies with these instruments have been carried out, and they have not yet been published or made available for professional use.

Another important issue to be addressed concerns the fact that the criteria and definitions that will determine whether an individual will be considered gifted depends on each culture and its values. However, the majority of these definitions include the recognition of the influence of cognitive, emotional, personality traits, and environmental conditions on the development of these behaviors (Mosquera, Stobäus, \& Freitas, 2014). Therefore, studies of the characteristics that would be common to these individuals have gained prominence, and 
these characteristics are usually investigated using external evaluation or self-report scales.

A number of characteristics that would be common to gifted individuals are available in the literature (Almeida et al., 2013; Davis et al., 2011a; Reis \& Renzulli, 2010; Sainz, Fernandés, \& Soto, 2012). These characteristics can grouped into four dimensions: cognitive ability (high level of abstract thought, adaptation to novel situations, observation, curiosity, reasoning, memory, flexibility); learning (early and rapid learning, intense interest, broad knowledge, verbal fluency, and mathematics and reading skills, among others); motivation (intrinsic, task-involvement, interest, and enthusiasm); and personality traits (leadership, persistence, self-confidence, imagination, creativity, and perfectionism). It has been observed that several personality traits associated with giftedness permeate the intellectual, social, emotional, and educational spheres in these individuals (Rotigel, 2003), and that it is important to understand how the grouping of all traits can result in gains in their development (Plucker \& Callahan, 2014; Russell, 2016).

Based on the discussions above and especially considering that difficulties still exist in the evaluation and identification of gifted individuals in the Brazil, whose scenario is marked by the challenges faced, among other things, and by the lack of instruments developed or adapted specifically for the Brazilian population, an instrument denominated Escala de Identificação de Características de Altas Habilidades/ Superdotação (EICAH/S, Scale for Identification of Characteristics of Giftedness) is under development.

The instrument was designed to be a selfreport scale since this format is easy to apply and it can be used as a screening instrument. Moreover, the knowledge of the individuals' perceptions of their own abilities and behaviors may be essential for their full understanding, and this is not a regularly used method; external observations, usually parents and teachers' evaluation are more commonly used (Freeman, 1996; Ona, 2016). This is the distinctive characteristic of the instrument being developed; it can be used to complement findings from other performance assessment procedures. Therefore, the present study aimed to investigate evidence of validity based on the internal structure of the scale that is being developed using exploratory factorial analysis and investigation of the reliability of its factors. The results are presented below.

\section{Method}

\section{Participants}

The sample consisted of 276 regular elementary and middle school students of both sexes $(60 \%$ female), aged 9 to 12 years old (Mean $-M=10.69$, Standard Deviation $-S D=1.00)$, attending three public schools that were selected based on convenience and were located in two cities in the state of São Paulo. The school grades investigated were as follows: fourth (20\%), fifth (32\%), sixth $(30 \%)$, and seventh (18\%) grades.

\section{Instrument}

Scale for Identification of Characteristics of Giftedness, this is a self-report scale and its initial version was composed of 44 items to be answered on a 4-point Likert scale ranging from: 1 = "Does not describe me at all", 2 = "Does not describe me very well", 3 = "Describes me somewhat", and $4=$ "Describes me very well". The items constitute behaviors representative of 22 common characteristics shared by gifted individuals, as previously mentioned. Some examples of items include: "When I'm part of a group, I like to decide what to do", "When I start to do something, even if it's difficult, I can finish it", and "I can easily answer questions on tests with only one correct answer".

Due to the age difference between the youngest (9 years) and the oldest participants (12 years) and the differences in the vocabulary development in these different phases of childhood and adolescence, the pilot study that was carried out (as previously mentioned) on 35 participants allowed the identification of words, phrases, and sentences, albeit in small number, which were not correctly understood by all participants. These 
terms were replaced by others according to the suggestions of the participants and were reviewed together with them; both younger and older students did not have difficulties in understanding the rewritten items in the new version (Bassinello, 2014)

\section{Procedures}

Since there are different theoretical models and their current understanding of giftedness as a multidimensional concept, when selecting the theoretical framework of the instrument the authors chose to focus on the characteristics that are usually associated with gifted individuals. The development of the instrument started by identifying, in the scientific literature, descriptive characteristics of individuals with high abilities, based on Pasquali's (2010) recommendations with regard to the need to define types and characteristics that will constitute the empirical representation of the latent traits, by reviewing relevant literature on the construct, in order to make it easy for the psychometrist to properly use them.

Therefore, a review of national and international scientific literature was conducted, regardless of publication date, in different databases (SciELO, American Psychological Association, Capes Journals, EBSCO), in addition to a search for printed books. All books and papers that clearly addressed characteristics associated with giftedness were selected. Thus, a total of 12 papers were identified and separated according to their origin: international papers (Almeida et al., 2013; Davis et al., 2011a; Jeltova \& Grigorenko, 2005; Johnsen, 2011); national papers (Alencar, 2007; Ferreira, 2013; Guenther, 2012; Lima, 2008; Ourofino \& Guimarães, 2007; Sabatella, 2012) and the definitions provided by the Ministry of Education (Ministério da Educação, 1999; 2006).

After identifying all characteristics listed by the authors identified, those that were present in at least four of the twelve articles reviewed were selected. Therefore, 22 characteristics (taskinvolvement/motivation, verbal fluency/large vocabulary, memory, curiosity, perfectionism, superior reasoning/problem solving skills, broad interests, moral reasoning/sense of justice, persistence, abstract/complex/logical thinking, ability to extrapolate knowledge to new situations, leadership, success in extracurricular activities, early and rapid learning, keen observation, emotional intensity/sensitivity, ability to empathize/offer help, and questioning skills). The adoption of this method to select the content to be evaluated by the scale is justified by the decision to evaluate the characteristics associated with giftedness instead of using a specific theoretical model; the models were reviewed and helped understand this phenomenon as a multidimensional construct. Given the fact that the scale was designed to be a self-report instrument, this method allowed the identification and analysis of a large number of descriptive characteristics that were found in consensus reports in the national and international literature.

Based on this selection, two items were created to evaluate each characteristic in order to prepare the first version of the instrument, which had 44 items. According to this version, two studies were carried out: search for evidence of validity based on content analysis that included a panel of judges (with revealed good results due to the percentage of agreement and Kappa values) and a pilot study (on 35 children to verify of the adequacy of the items to the targeted age group; the students' suggestions led to the review of few words, phrases, and sentences). For more detailed information on the development of the scale and the results obtained in these preliminary studies, please refer to Bassinello (2014).

The present study was carried out following approval by the Research Ethics Committee of the Pontifícia Universidade Católica de Campinas, Protocol $n^{\circ}$ 762.774, 08/08/2014. The Informed Consent Form was sent to the students' parents/ guardians two weeks before the administration of the instrument. The parent/guardian consenting signatures and assent from students older 10 years old were required for students' participation. The instrument was administered collectively in a single session in classrooms, and no time limit was set for answering the questions (mean time was thirty 
minutes). No answer form was discarded because all participants answered all questions without leaving any blanks.

It is worth mentioning that the sample used in this study did not include participants who had been already identified as gifted or who had participated in specific stimulating programs. This decision was based firstly on the need to carry out previous studies with the instrument being developed in order to verify some of its psychometric properties for subsequent administration to the target population. Thus, considering that this is one of the first empirical psychometric investigations on the EICAH/S and that further studies will be carried out on this instrument to confirm its psychometric properties (such as other types of validity, accuracy, and standardization), a study focusing on this specific population will be carried out investigating evidence for criterion-related validity, after examining the internal structure of this scale. We believe that these decisions may have significantly influenced the results, which is one of the limitations of the present study.

In order to meet the objective of this study, an Exploratory Factor Analysis (EFA) was carried out, and the Unweighted Least Squares estimation and the Promax oblique rotation methods were used, based on a polychoric correlation matrix due to the adequacy of this procedure to evaluation of ordinal scale data (Holgado-Tello, Chacón-Moscoso, Barbero-García, \& Vila-Abad, 2010) and violations of multivariate normality assumption for these variables (Mardia = 35.757, $p \leq 0.01$; Mardia, 1970). The factor retention criteria were as follows: factor saturation higher than 0.30; Scree Plot; GuttmanKaiser criterion, Parallel Analysis; and interpretability criteria. Internal consistency was measured using Cronbach's alpha coefficient. The analyses were carried out using the Statistical Package for the Social Sciences (SPSS Inc., Chicago, Illinois, United States) statistics version 20 and Factor version 10.3 (Lorenzo-Seva, Timmerman, \& Kiers, 2011).

\section{Results}

Prior to Exploratory Factor Analysis, KaiserMeyer-Olkin (KMO) and Bartlett test of Sphericity were used to test the suitability of the data for EFA. KMO value of 0.86 and Bartlett's test of sphericity, $\chi^{2}(\mathrm{gL})=3419.4, p<0.01$, indicated that the data were adequate for factor analysis. The decision about how many factors to retain was based on the Guttman-Kaiser criterion (eigenvalues greater than 1 are retained) and the Scree Plot; both methods indicated a two-factor solution. Finally, the previously suggested solution was confirmed using the Parallel Analysis based on Minimum Rank Factor Analysis (Timmerman \& Lorenzo-Seva, 2011), generating 500 random polychoric correlation matrices simulated using Permutation of the Raw Data (Buja \& Eyuboglu, 1992). Parallel analysis showed that only the first two variances derived from real data had values higher than those derived from the random matrices $33.3 \%$ and $7.1 \%$ of real data versus $9.2 \%$ and $5.3 \%$ of the mean random data). The final factor solution, a two-factor solution, explained $40.4 \%$ of the total variance.

Factor 1 explained $33.3 \%$ of the variance grouping 23 items $(5,6,7,9,12,13,14,15,17,18$, $19,21,24,26,27,30,32,33,34,35,36,37,40$, and 42 ) referring basically to the individual's social and emotional abilities, i.e., the individuals' ability to care for others, to be persistent, to be interested in different types of subjects, to frequently observe the world around them, and to use their creativity and leadership through their good communication skills. Considering that the commonalities among the items were higher than 0.40 , and the factor loads were higher than 0.30 , this factor solution proved to be fully satisfactory.

Factor 2 explained $7.1 \%$ of the variance and was made up of 15 items $(3,8,10,11,16,20,23$, $28,29,31,38,39,43$, and 44). Its contents were related to cognitive and academic abilities, i.e., abstract and logical thinking, learning fast and in an insightful way, and interest for activities with right or wrong answers, and solving problems based on the ability to extrapolate knowledge to new situations. Again, all items had factorial loads higher than 0.30 .

It is important to highlight that six items $(1,2,4,22,25$, and 41) were not loaded to any of the factors and were excluded. Therefore, the 
first version of the instrument, composed of 44 items, was reduced to 38 items. Subsequently, the accuracy of the instrument was estimated, and it was possible to observe that both factors had desirable level of internal consistency, i.e., Cronbach's alpha coefficients for the first factor was 0.93 , and for the second factor it was 0.91 .

\section{Discussion}

The results of the factorial analysis indicated that this scale has evidence of validity based on the internal structure, which is an important step towards establishing its psychometric properties (American Psychological Association, American Educational Research Association \& National Council on Measurement in Education, 2014). Data analyses revealed that the characteristics evaluated by EICAH/S were grouped into two factors, indicating a two-dimensional structure for the self-report scale studied.

This factor solution corroborates the expanded conception of giftedness, according to which, the phenomenon encompasses not only cognitive aspects, but also social and emotional characteristics. This is the conception found in the major models related to this topic, for example in Theory of Multiple Intelligences (Davis et al., 2011a), The Differentiating Model of Giftedness and Talent (Gagné, 2014), Wisdom, Intelligence, Creativity, Synthesized (Sternberg, 2003), or the Three-Ring Conception of giftedness (Renzulli, 2014); These models recognize the importance of including emotional, social, and environmental aspects to understand the phenomenon, and they indicate the manifestation of the phenomenon in different domains, demonstrating its heterogeneity and individual differences.

The international scenario is characterized by the existence of different instruments that evaluate the various aspects of Giftedness and encompass cognitive and behavioral attributes of the gifted individuals (Davis et al., 2011a; Kaufman, Plucker, \& Russell, 2012; Pfeiffer \& Jarosewic, 2003; Ribeiro, Nakano, \& Primi, 2014). Thus, the internal structure of the scale studied, which is composed of two factors (cognitive and socio-emotional) is in line with current trends in study of this topic since it recognizes the influence of different types of characteristics other than the cognitive abilities on the expression of giftedness.

Accordingly, the first factor of the EICAH/S was denominated "Socio-emotional Characteristics" because the analysis of the content of its items indicates the description of the individual's social and emotional abilities, especially related to affective development, values, self-concept, motivation, and attitudes. These characteristics are related to the interpersonal or intrapersonal intelligence in the Model proposed by Gardner (1998) and to the socio-affective ability in the model developed by Gagné (2014). They indicate that gifted individuals may have the ability to understand their own feelings and those of other people and to discriminate between their emotions and use them to regulate their behavior, and they may have higher level of moral responsibility than their peers (Karatas \& Saricam, 2016).

The characteristics in this first factor are in accordance with the socio-emotional abilities of gifted individuals reported in the scientific literature (Almeida et al., 2013; Davis et al., 2011b; Johnsen, 2011; Karatas \& Saricam, 2016; Lima, 2008; Ourofino \& Guimarães, 2007; Renzulli, 2012; Sabatella, 2012), such as high sensitivity, emotional intensity, valorization of cooperative and democratic interactions, positive feelings towards others, advanced moral development, high level of self-efficacy, higher level of maturity than peers, leadership, altruism, motivation, sense of justice, and sense of humor.

Particular attention should be given to the fact that the items related to creativity were grouped in this factor. Although this construct is composed of cognitive and emotional elements (Torrance \& Ball, 1990), and thus it could belong to any of the two factors in the factor solution, the fact that these items were inserted in the factor related to socio-emotional aspects can be explained by the content of these items. The creative aspects addressed were more closely related to social aspects ("People always say I'm creative"). 
A broader view encompassing emotional, behavioral, and social aspects is essential since cognitive aspects have historically been considered more frequently in evaluation and intervention processes. It is worth highlighting that the presence of these characteristics could be one of the indicators of giftedness when considered in conjunction with other processes used in the identification of these individuals. It is also important to emphasize that these characteristics can be determined by result from opportunities, level of stimulation, and personal experiences. Similarly, it is worth mentioning that they may be present to a greater or lesser extent, isolated or combined, which will determine the emotional or social adjustment of gifted individuals.

They may be present in individuals, but due to misinterpretations of the unique behaviors and communication styles of gifted individuals (Wellisch \& Brown, 2012), and depending on the amount of attention given by their educational, family, and social contexts to their especial and particular needs, they can result in a negative outcome (extreme perfectionism, low self-esteem), as emphasized by Davis et al. (2011a). These characteristics can also be associated with a mental, learning, physical, and sensory processing disorders, in cases called dual exceptionality, which refers to the presence of high abilities in one or more areas, along with disabilities or conditions that are incompatible with these characteristics (Neihart, 2008). As an example, in the field of cognitive psychology, there are cases of gifted children who have neurodevelopmental disorders, such as Asperger's Syndrome, Attention Deficit Hyperactivity Disorder, and Learning Disorders, among others (Alves \& Nakano, 2015).

The second factor was denominated "Cognitive Characteristics" because it is closely related to academic skills, specific skills, logical and deductive thinking, problem-solving processes and strategies, information organization, and cognitive styles. The characteristics included in this second factor are similar to those pointed out by several researchers as characteristics of individuals with giftedness, such as high ability to differentiate information received, good spatial awareness, ability to perceive similarities and differences, ability to make rapid associations, deduction of principles, greater speed and depth of learning than peers, higher organizational abilities, use of routine and efficient strategy for information access (Almeida et al., 2013; Davis et al., 2011a; Ferreira, 2013; Guenther, 2012; Johnsen, 2011).

The importance of intellectual and cognitive abilities has been emphasized in different theories and models of giftedness aiming to understand these abilities based on expanded concepts that are not exclusively related to intelligence. Thus, Gardner's Theory of Multiple Intelligences (1983) represents these characteristics in three major different modalities: linguistic, logical-mathematical, and spatial intelligences. In the model proposed by Gagné (2014), they are highlighted through the intellectual domain, represented by analytical thinking, sense of observation, memory, verbal and spatial thinking. The developmental model for creative productivity proposed by Renzulli (2014), The Three-Ring Conception of giftedness, includes the above average ability trait, which can be defined in two ways: general ability, which is related to general intelligence (verbal and numerical reasoning, spatial relations, memory), and specific abilities (broad range of specific abilities in different areas), which is one of the components interacting with high abilities. According to this author, academic talent includes high levels of school performance, good memory, great intellectual activity, complex information processing, and analytical, critical, and logical thinking. Sternberg (2003) also referred to cognitive ability as analytical intelligence, characterized by analysis, evaluation, comparison and contrast, and logical judgment when solving abstract problems.

The review of international literature on the instruments available to identify gifted individuals indicated the importance of considering that not only intelligence or cognitive aspects define Giftedness. However, these aspects contribute, at the same level as the socio-emotional aspects, to promote a more comprehensive view of gifted individuals (Mosquera et al., 2014; Renzulli, 2014). Therefore, there has been an acceptance of the 
premise that gifted individuals needs are not related only to the intellectual and academic areas, but they also pervade the artistic, social and emotional areas (Almeida et al., 2013), which corroborates the multifactor structure of the EICAH/S.

Considering this, it is worth mentioning that this scale was designed to be one of the possible instruments used in the initial screening of behaviors associated with giftedness due to advantages of this instrument format, which are mainly related to its ease of application and potential use on a large scale for collective assessment. However, considering that only some aspects are covered by the contents of its items and the instrument limitation since it is a self-report measure, it is recommended that it be used in conjunction with other methods of evaluation, such as performance tests that assess intelligence and creativity and parent and teacher assessment scales to identify a wider range of individuals with different profiles.

It should be noted that the results presented here are the results of one of the first psychometric investigations of the scale. Therefore, further investigations of evidence of validity based on relationships with other variables - criterion validity, comparing control group and criterion group (individuals previously Identified as gifted, aiming to verify if the instrument can differentiate between individuals with giftedness) - and convergent and discriminant validity, as well as accuracy, are needed. With regard to the limitations of this study, it is important to highlight that the sample used was composed only by individuals enrolled in public schools in only one state in the entire country. Moreover, the scale was not administered to children who had been previously identified as gifted by programs targeting this specific population.

Therefore, future studies using this instrument with minority groups, such as individuals with dual exceptionality, should be carried out aiming at identifying a larger number of individuals by an instrument suited to their particularities and that considers the linguistic, cultural, and social characteristics of Brazil, as well as the definition of giftedness that has guided the development of the public policies adopted here. These aspects, together with the difficulties that could be faced by the authors related to the adaptation of internationally available instruments (such as copyright and restrictions imposed by the publishers), which may hinder necessary changes and adjustments in those instruments, motivated the development of a novel and national instrument. Therefore, it is expected that these new studies will produce positive results so that, in the future, this instrument can be made available for professional use.

\section{Acknowledgment}

The authors are grateful for the financial support provided by Conselho Nacional de Desenvolvimento Científico e Tecnológico.

\section{Contributions}

P. ZAIA contributed to the conception and design of this study, to data interpretation, and to the final revision of the manuscript. T.C. NAKANO contributed to the conception of this study, to data interpretation, and to the final revision of the manuscript. E.M. PEIXOTO contributed to the analysis of the results.

\section{References}

Alencar, E. M. L. S. (2007). Características socioemocionais do superdotado: questões atuais. Psicologia em Estudo, 12(2), 371-378. https://doi.org/10.1590/\$1413-73 722007000200018

Almeida, L. S., Fleith, D. S., \& Oliveira, E. P. (2013). Sobredotação: respostas educativas. Braga: ADIPSIEDUC.

Almeida, L. S. \& Primi, R. (2010). Considerações em torno da medida de inteligência. In L. Pasquali. Instrumentação psicológica: fundamentos e práticas (pp. 386-410). Porto Alegre: Artmed.

Alves, R. J. R., \& Nakano, T. C. (2015). A dupla excepcionalidade: relações entre altas habilidades/superdotação com a Síndrome de Asperger, Transtorno de Déficit de Atenção e Hiperatividade e Transtornos de Aprendizagem. Psicopedagogia, 32, 346-360. Recuperado em 26 dezembro, 2016, de http://pepsic.bvsalud.org/pdf/ psicoped/v32n99/08.pdf

American Psychological Association, American Educational Research Association \& National Council on 
Measurement in Education. (2014). Standards for educational and psychological testing. Washington: American Psychological Association.

Bassinello, P. Z. (2014). Construção de escala de autorrelato para identificação de características associadas à superdotação (Dissertação de mestrado não-publicada). Pontifícia Universidade Católica de Campinas.

Bracken, B. A., \& Brown, E. F. (2006). Behavioral identification and assessment of gifted and talented students. Journal of Psychoeducational, 24(2), 112122. https://doi.org/10.1177/0734282905285246

Buja, A., \& Eyuboglu, N. (1992). Remarks on parallel analysis. Multivariate Behavioral Research, 27(4), 509540. https://doi.org/10.1207/s15327906mbr2704_2

Calero, M. D., \& García-Martin, M. B. (2014). Estabilidad temporal del C.I. y potencial de aprendizaje en ninos superdotados: implicaciones diagnósticas. Anales de Psicologia, 39(2), 512-521. https://doi.org/10.6018/ analesps.30.2.16380

Cardoso, A. O. G., \& Becker, M. A. A. (2014). Identificando adolescentes em situação de rua com potencial para altas habilidades/superdotação. Revista Brasileira de Educação Especial, 20(4), 605-614. https://doi. org/10.1590/s1413-65382014000400011

Davis, K., Christodoulou, J., Seider, S., \& Gardner, H. (2011a). The Theory of Multiple Intelligences. In R. J. Sternberg \& S. B. Kaufman (Eds.), The Cambridge handbook of intelligence (pp. 485-503). New York: Cambridge University Press.

Davis, G. A., Rimm, S. B., \& Siegle, D. (2011b). Education of the gifted and talented. Boston: Pearson.

Ekinci, B. (2014). The relationships among Sternberg's Triarchic Abilities, Gardner's Multiple Intelligences, and academic achievement. Social Behavior and Personality, 42(4), 625-634. https://doi.org/10.2224/ sbp.2014.42.4.625

Farias, E. S. (2012). Elaboração de instrumento para identificação de alunos intelectualmente dotados por professores: estudo exploratório (Dissertação de mestrado não-publicada). Pontifícia Universidade Católica de Campinas.

Ferreira, J. F. C. (2013). Hannah, uma trajetória de superação. In D. S. Fleith \& E. M. L. S. Alencar (Orgs.), Superdotados: trajetórias de desenvolvimento e realizações (pp. 41-53). Curitiba: Juruá.

Folsom, C. (2009). Attitudes of gifted children. In B. Kerr (Ed.), Encyclopedia of giftedness, creativity and talent (pp. 1-4). Thousand Oaks, CA: Sage Publications.

Freeman, J. (1996). Self-reports in research on high ability. High Ability Studies, 7(2), 191-201. https://doi. org/10.1080/0937445960070209

Gagné, F. (2014). The DMGT: changes within, beneath, and beyond. In F. H. R. Piske, J. M. Machado, S. Bahia,
\& T. Stoltz (Orgs.), Altas habilidades/superdotação: criatividade e emoção (pp. 21-44). Curitiba: Juruá.

Gallagher, J. J. (2008). Psychology, psychologist, and gifted students. In S. Pfeiffer (Org.), Handbook of giftedness in children: Psycho-educational theory, research and best practices (pp. 1-11). New York: Springer.

Gardner, H. (1983) Frames of mind. New York: Basic Books.

Gardner, H. (1998). A multiplicity of intelligences. Scientific American Presents, 9, 18-23. Retrived July 19, 2016, from http://web.b.ebscohost.com/ehost/ detail/detail?sid=8641f260-1672-4715-932f $-1511 \mathrm{bd}$ $830496 \% 40$ sessionmgr106\&vid=0\&hid=102\&bdata $=$ Jmxhbmc9cHQtYnImc2|0ZT1laG9zdC 1 saXZl\#AN= 20940674\&db=aph

Guenther, Z. C. (2012). Quem são os alunos dotados? Reconhecer dotação e talento na escola. In L. C. Moreira \& T. Stoltz (Orgs.), Altas habilidades/superdotação, talento, dotação e educação (pp. 63-83). Curitiba: Juruá.

Heller, K. A. (2013). Findings from the Munich longitudinal study of giftedness and their impact on identification, gifted education and counseling. Talent Development \& Excellence and Counseling, 5(1), 51-64. Retrived February 22, 2017, from http://www.iratde.org/ images/TDE/2013-1/tde2013-1-05heller.pdf

Hérnandez-Torrano, D., Férrandiz, C., Ferrando, M., Prieto, L., \& Férnandez, M. C. (2014). The theory of multiple intelligences in the identification of high abilities students. Anales de Psicologia, 30(1), 192200. https://doi.org/10.6018/analesps.30.1.148271

Holgado-Tello, F. P., Chacón-Moscoso, S., Barbero-García, I., \& Vila-Abad, E. (2010). Polychoric versus Pearson correlations in exploratory and confirmatory factor analysis of ordinal variables. Quality and Quantity, 44(1), 153-166. https://doi.org/10.1007/s11135-008-9190-y

Jeltova, I., \& Grigorenko, E. L. (2005). Systemic approaches to giftedness. In R. J. Sternberg \& J. E. Davidson (Eds.), Conception of giftedness (pp. 171-186). Cambridge: Cambridge University Press.

Johnsen, S. K. (2011). Definitions, models, and characteristics of gifted students. In S. K. Johnsen (Ed.), Identifying gifted students: A practical guide (pp. 1-35). Texas: Prufrock Press Inc.

Jones, D. E., Greenberg, M., \& Crowley, M. (2016). How children's social behaviors relate to success in adulthood. The WERA Educational Journal, 8(2), 27-33.

Karatas, Y., \& Saricam, H. (2016). The relationship between moral maturity and sense and behaviors of responsibility in gifted children. Global Journal of Psychology Research, 6(1), 10-19.

Kaufman, J. C., Plucker, J. A., \& Russell, C. M. (2012). Identifying and assessing creativity as a component 
of giftedness. Journal of Psychoeducational Asessment, 30(1), 60-73. https://doi.org/10.117 7/0734282911428196

Kaufman, S. B. \& Sternberg, R. J. (2008). Conceptions of giftedness. In S. Pfeiffer (Ed.), Handbook of giftedness in children: Psycho-Educational theory, research and best practices (pp. 71-91). New York: Springer.

Lima, D. M. M. P. (2008). A identificação e inclusão do aluno com altas habilidades/superdotação na rede pública de ensino do Estado o Paraná. Universidade Federal do Paraná, Curitiba, PR, Brasil. Recuperado em 15 outubro, 2013, de http://www.diaadiaeducacao. pr.gov.br/portals/pde/arquivos/1075-2.pdf

Lorenzo-Seva, U., Timmerman, M. E., \& Kiers, H. A. L. (2011). The hull method for selecting the number of common factors. Multivariate Behavioral Research, 46, 340-364. https://doi.org/10.1080/00273171.20 11.564527

Mardia, K. V. (1970). Measures of multivariate skewness and kurtosis with applications. Biometrika, 57(3), 519-530. https://doi.org/10.2307/2334770

McClain, M., \& Pfeiffer, S. (2012). Identification of gifted students in the United States today: A look at state definitions, policies and practices. Journal of Applied Psychology, 28(1), 59-88. https://doi.org/10.1080/15 377903.2012.643757

Mettrau, M. B., \& Reis, H. M. M. S. (2007). Políticas públicas: altas habilidades/superdotação e a literatura especializada no contexto da educação especial/inclusiva. Ensaio: Avaliação e Políticas Públicas em Educação, 15(57), 489-510.

Milligan, J. L. (2010). Assessment of giftedness: A concise and practical guide (2nd ed.). New York: YBK Publishers.

Ministério da Educação (Brasil). (1999). Programa de capacitação de recursos humanos do ensino fundamental. Brasília: MEC. Recuperado em 4 setembro, 2013, de http://www.dominiopublico.gov.br/ download/texto/me002302.pdf

Ministério da Educação (Brasil). (2006). Saberes e práticas da inclusão: desenvolvendo competências para o atendimento às necessidades educacionais especiais de alunos com altas habilidades/superdotação. Brasília: Autor. Recuperado em 15 outubro, 2013, de http:// portal.mec.gov.br/seesp/arquivos/pdf/altashabilidades. pdf

Mosquera, J. J. M., Stobäus, C. D., \& Freitas, S. N. (2014). Altas habilidades/superdotação no transcurso da vida: da infância à adultez. In A. M. R. Virgolim \& E. C. Konkiewitz (Orgs.), Altas habilidades/superdotação, inteligência e criatividade (pp. 265-282). Campinas: Papirus.

Mun, R. U. (2016). Identifying and assessing highly capable students. The WERA Educational Journal, 8(2), 14-17. Retrived August 15, 2016, from http:// www.wera-web.org/wp-content/uploads/2012/08/ WEJ-May-2016-final.pdf

Nakano, T. C., Campos, C. R., \& Santos, M. V. (2016). Escala de avaliação de altas habilidades/superdotação: versão professor validade de conteúdo. Estudos Interdisciplinares em Psicologia, 7(1), 103-123. https:// doi.org/10.5433/2236-6407.2016v7n1p103

Nakano, T. C., Gozzoli, M. Z., Alvez, R. J. R., Zaia, P., \& Campos, C. R. (2016). Investigación de la eficacia de una escala de evaluación de altas habilidades versión profesor. Revista de Estudios y Experiencias en Educación, 15, 83-94. https://doi.org/10.21703/ rexe.20162983945

Nakano, T. C., Primi, R., Abreu, I. C. C., Gozzoli, M. Z., Caporossi, D. C., Miliani, A. F. M., \& Martins, A. A. (2015). Bateria para avaliação das altas habilidades/ superdotação: análise dos itens via Teoria de Resposta ao Item. Estudos de Psicologia (Campinas), 32(4), 729-741. https://doi.org/10.1590/0103-166X2015 000400016

Nakano, T. C., Primi, R., Ribeiro, W. J., \& Almeida, L. S. (2016). Evaluación multidimensional de la superdotación: criterios de validez de la bateria de inteligencia y creatividad para predecir los talentos artisticos y académicos. Anales de Psicología, 32, 628-637. https:// doi.org/10.6018/analesps.32.3.259391

Nakano, T. C., \& Siqueira, L. G. G. (2012). Validade de conteúdo da Gifted Rating Scale (versão escolar) para a população brasileira. Avaliação Psicológica, 11(1), 123-140. Recuperado em 14 dezembro, 2016, de http:// pepsic.bvsalud.org/pdf/avp/v11n1/v11n1a12.pdf

Neihart, M. (2008). Identifying and providing services to twice exceptional children. In S. Pfeiffer (Org.), Handbook of giftedness in children: Psycho-educational theory, research and best practices (pp. 115-137). New York: Springer.

Olszewski-Kubilius, P., Subotnik, R. F., \& Worrell, F. C. (2015). Conceptualizations of giftedness and the development of talent: Implications of counselors. Journal of Counseling and Development, 93, 143-152. https://doi.org/10.1002/j.1556-6676.2015.00190.x

Ona, A. (2016). Auto-nomination inventory for identifying the talent in the technical field. In A. Zamosteanu (Ed.), Theoretical and applied in psychology (pp. 13-16). Bologna: Medimond.

Ourofino, V. T. A. T., \& Guimarães, T. G. (2007). Características intelectuais, emocionais e sociais do aluno com altas habilidades/superdotação. In D.S. Fleith (Org.), A construção de práticas educacionais para alunos com altas habilidades/superdotação (pp. 41-51). Brasília: MEC.

Panov, V. I. (2002). Gifted children: Identification, teaching and development. Russian Education and Society, 44(10), 52-80. https://doi.org/10.2753/ res1060-9393441052 
Pasquali, L. (2010). Testes referentes a construto: teorias e modelos de construção. In L. Pasquali (Org.), Instrumentação psicológica: fundamentos e prática (pp. 165-198). Porto Alegre: Artmed.

Pérez, S. G. P. B., \& Freitas, S. N. (2014). Políticas públicas para as altas habilidades/superdotação: incluir ainda é preciso. Revista Educação Especial, 27(50), 627-640. https://doi.org/10.5902/1984686X14274

Pfeiffer, S., \& Blei, S. (2008). Gifted identification beyond the iq test: Rating scales and other assessment procedures. In S. Pfeiffer (Ed.), Handbook of giftedness in children: Psycho-Educational theory, research and best practices (pp. 177-198). New York: Springer.

Pfeiffer, S., \& Jarosewich, T. (2003) Gifted Rating Scales: manual. San Antonio, TX: Pearson.

Pfeiffer, S. I., \& Petscher, Y. (2008). Identifying young gifted children using the Gifted Rating Scales-Preschool/ Kindergarten Form. Gifted Child Quartely, 52(1), 19-29. https://doi.org/10.1177/0016986207311055

Plucker, J. A., \& Callahan, C. M. (2014). Research on giftedness and gifted education: Status of the field and considerations for the future. Exceptional Children, 80(4), 390-406. https://doi.org/10.1177/0014402914527244

Reis, S. M., \& Renzulli, J. S. (2010). Is there still a need for gifted education? An examination of current research. Learning and Individual Differences, 20(4), 308-317. https://doi.org/10.1016/j.lindif.2009.10.012

Renzulli, J. S. (2012). Reexamining the role of gifted education and talent development for the 21st Century: A four-part theoretical approach. Gifted Child Quartely, 56(3), 150-159. https://doi.org/10.1177/0 016986212444901

Renzulli, J. S. (2014). A concepção de superdotação no Modelo dos Três Anéis: um modelo de desenvolvimento para a promoção da produtividade criativa. In A. M. R. Virgolim \& E. C. Konkiewitz (Orgs.), Altas habilidades/ superdotação, inteligência e criatividade (pp. 219-264). Campinas: Papirus.

Renzulli, J. S., Siegle, D., Reis, S. M., \& Gavin, M. K. (2009). An investigation of the reliability and factor structure of four new Scales for rating the Behavioral Characteristics of superior Students. Journal of Advanced Academics, 21(1), 84-108. https://doi. org/10.1177/1932202X0902100105

Ribeiro, W. J., Nakano, T. C., \& Primi, R. (2014). Validade da estrutura fatorial de uma bateria de avaliação de altas habilidades. Psico, 45(1), 100-109. https://doi. org/10.15448/1980-8623.2014.1.13636
Rotigel, J. V. (2003). Understanding the youth gifted children: Guidelines for parents, families and educators. Early Childhood Education Journal, 30(4), 209-214. https://doi.org/10.1023/a:1023331422963

Russell, S. J. (2016). Cognitive and noncognitive measures as predictors of student success at an independent school (Unpublished doctoral dissertation). Philadelphia College of Osteopathic Medicine Department of Psychology.

Ryser, G. R. (2011). Qualitative and quantitative approaches to assessment. In S. K. Johnsen (Ed.), Identifying gifted students: A practical guide (2nd ed., pp. 37-61). Waco: Prufrock Press Inc.

Sabatella, M. L. P. (2012). Expandir horizontes para compreender alunos superdotados. In L. C. Moreira \& T. Stoltz (Orgs.), Altas habilidades/superdotação, talento, dotação e educação (pp. 113-128). Curitiba: Juruá.

Sainz, M., Fernandés, M. C., \& Soto, G. (2012). Inteligência emocional y alta habilidad. Revista Amazônica, 10(3), 186-203. Recuperado en 26 diciembre, 2016, de https:// dialnet.unirioja.es/servlet/articulo?codigo=4047576

Secretaria de Educação Especial (Brasil). (2012). Políticas públicas para alta habilidade/superdotação. Brasília: Senado Federal. Recuperado em fevereiro 22, 2012, de http://www.senado.gov.br/web/comissoes/CE/ AP/AP20080626_superdotados_CI\%C3\%A1 udia Griboski.pdf

Sternberg, R. J. (2003). Wisdom, intelligence and creativity synthetized. Cambridge: Cambridge University Press.

Sternberg, R. J. (2005). The WICS Model of giftedness. In R. J. Sternberg \& J. E. Davidson (Eds.), Conception of giftedness (pp. 327-324). Cambridge: Cambridge University Press.

Timmerman, M. E., \& Lorenzo-Seva, U. (2011). Dimensionality assessment of ordered polytomous items with parallel analysis. Psychological Methods, 16(2), 209-220. https://doi.org/10.1037/a0023353

Torrance, E. P., \& Ball, O. E. (1990). Streamlined scoring and interpretation guide and norms manual verbal and gural form $B$. Bensenville: Scholastic Testing Service.

Wellisch, M., \& Brown, J. (2012). An integrated identification and intervention model for intellectually gifted children. Journal of Advanced Academics, 23(2), 145-167. https:// doi.org/10.1177/1932202X12438877

Received: August 9, 2016

Final version: February 22, 2017

Approved: March 7, 2017 